\title{
TrêS FORMAS MUTANTES DO "EU MESMO"
}

Manlio M. Speranzini ${ }^{1}$

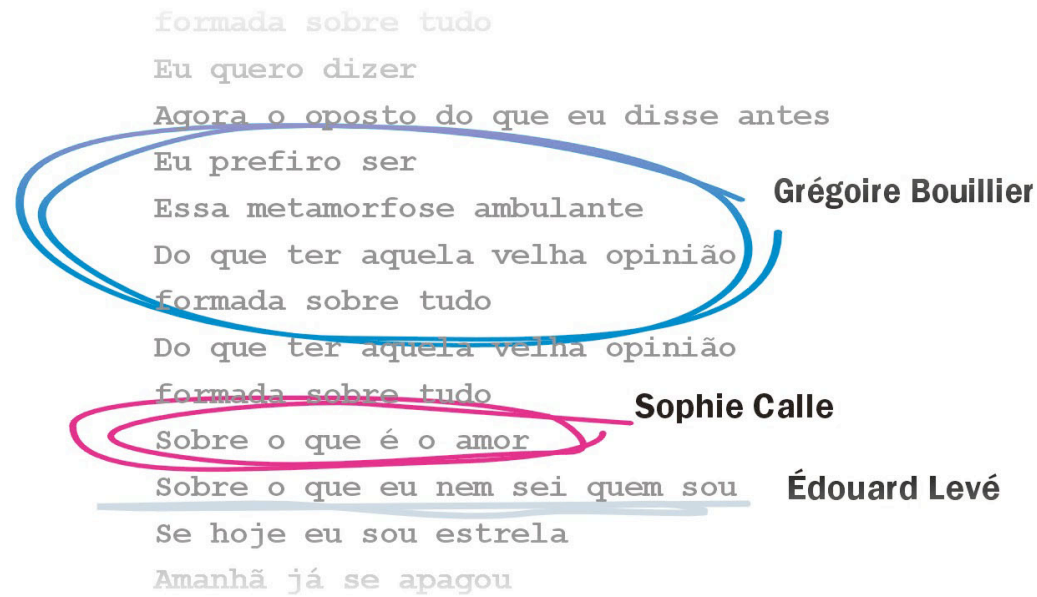

Eu não ouço outra coisa! Às vezes muda a voz, o arranjo, mas a letra é a mesma. Ouço isso desde que comecei a pensar numa coerência que me permitisse reunir, de uma só vez, três resenhas: Rapport sur moi, de Grégoire Bouillier; Histórias Reais, de Sophie Calle; e Autoportrait, de Édouard Levé. De tanto ouvir a canção, comecei a identificar nas suas palavras a presença dos autores das obras resenhadas. Não reconheço uma relação direta entre essa canção e um dos livros em particular, mas ela me permite falar em generalidades: o 'Eu' da narrativa em primeira pessoa; o estado de metamorfose ambulante que acompanha os autores em suas histórias; e a forma mutante de cada livro, desvio do gênero autobiográfico. Para confirmar o estranhamento que particulariza e diferencia cada indivíduo, Grégoire Bouillier diz buscar uma linguagem que recomponha suas memórias e propõe como gênero literário o 'relato'; Sophie Calle, acreditando na força da complementaridade dos meios, apresenta um 'álbum' de fotografias e textos que cobrem e curam suas dores de 'ausência'; e, por fim, Édouard Levé, exibe as peças de um quebra-cabeça que é a própria 'impressão' do seu cérebro perturbado.

Os três autores afirmam em entrevistas que tiveram (ou ainda têm) no exercício da escrita um procedimento terapêutico na formulação/resolução de seus conflitos e inquietações pessoais: eles produzem suas obras para saber, para entender, para superar ou para registrar as impressões e dúvidas que acompanham suas vidas. Nenhum deles assume como estímulo inicial dessas produções o 'fazer literatura'. Eles não vivem para escrever, mas escreveram o que escreveram para conseguir viver.

\footnotetext{
1 Graduado em Arquitetura (FAU/USP), Mestre em Estética e História da Arte (PGEHA/USP) e Doutorando do Programa de Pós-Graduação em Língua e Literatura Francesa (FFLCH/USP). E-mail: manlio@usp.br.
} 
Nesse universo de autores-de-si e de desvios, eu também mutante, da palavra fotografada. dou minha contribuição num exercício do 'eu mesmo': por alguns momentos deixei minhas ações de pesquisador/investigador para atuar no campo da materialidade, invadindo o espaço da literatura, buscando outros diálogos, explicitando as ações de um leitor/manipulador e construindo uma forma ambígua, também
The Iaco amox

É chato chegar

A um objetivo num instante

Eu qua..

Nessa metamorfose ambulante

Do que ter aquela velha opinião

E a canção continua tocando na minha cabeça.

\section{Manlio Speranzini}
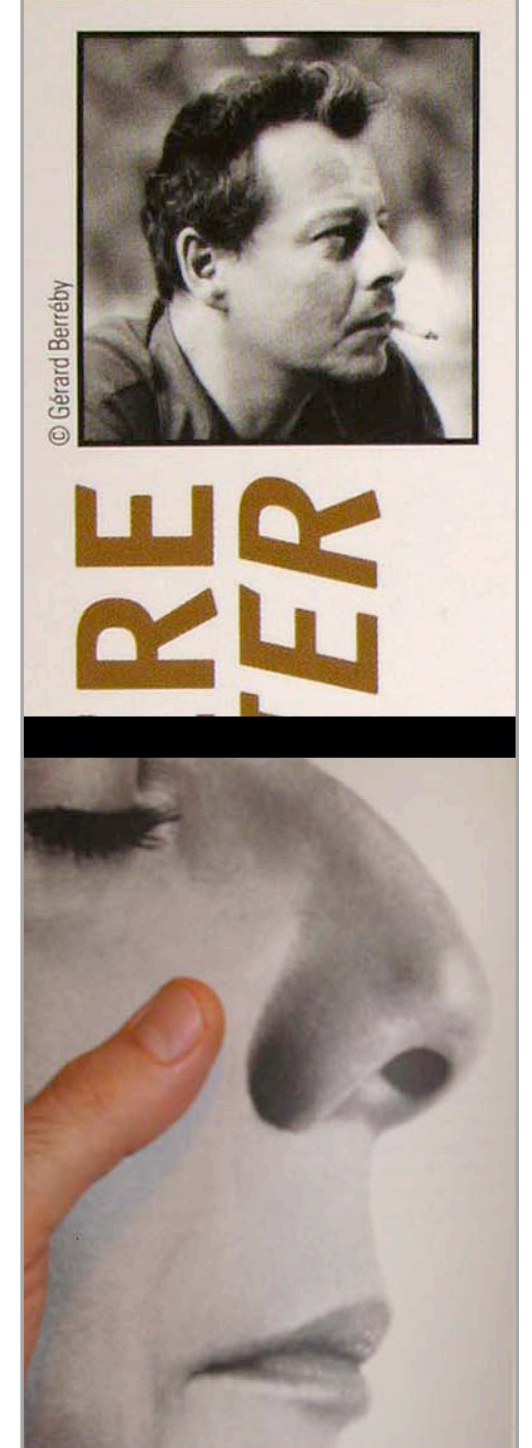

Aquilo tudo que eu lhe disse antes

Eu prefiro ser

Essa metamorfose ambulante

Do que ter aquela velha opinião

formada sobre tudo

Do que ter aquela velha opinião

formada sobre tudo

Do que ter aquela velha opinião

formada sobre tudo

Do que ter aquela velha

velha velha velha velha

Opinião formada sobre tudo

Do que ter aquela velha opinião

formada sobre tudo

Metamorfose Ambulante, Raul Seixas

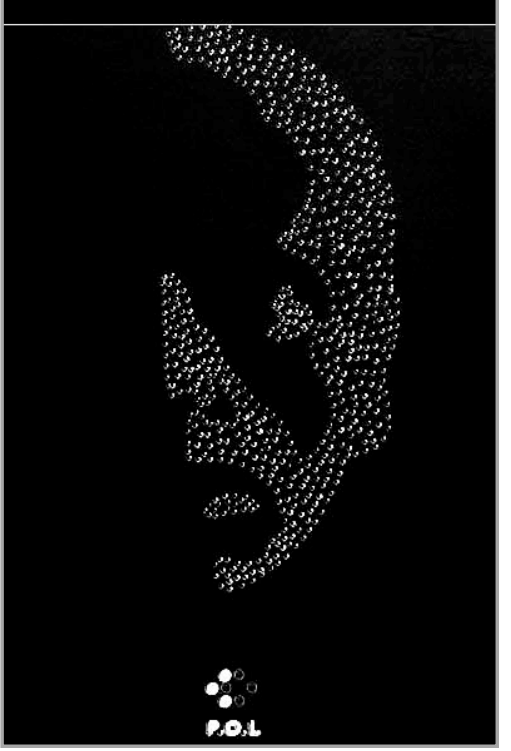


Grégoire Bouillier. Rapport sur moi. Paris: J'ai lu, 2004. 127p.

\section{O PROTOCOLO DE UMA VIDA ALUCINADA}

"Você é um filho do amor", dizia a mãe de Grégoire quando ele ainda era pequeno. Ele não entendia o que ela queria dizer com isso. Em público, ela também costumava fazer comentários a respeito da sua pele morena e de como seus traços não eram os de um Bouillier. A explicação viria muito mais tarde, dada pela própria mãe: no momento da sua concepção teria havido a participação de uma terceira pessoa e Grégoire seria filho de dois homens. A mãe também dizia ter encontrado numa revista científica uma explicação para esse fato inusitado: se dois homens ejaculassem na vagina de uma mulher, seus espermatozoides se fundiriam para fecundar o óvulo, dando origem a um 'mutante'.

Dito assim, ainda no início, a palavra 'mutante' assinala três aspectos que marcam essa narrativa autobiográfica: o primeiro é da ordem do desvio, reconhecido no baralhamento dos papéis de cada membro da família Bouillier; o segundo é da ordem da movimentação frenética dos acontecimentos vividos pelo autor e que são descritos no texto em saltos cronológicos e espaciais; e o terceiro é da ordem do gênero, já que o autor não aceita a definição de 'autobiografia' para esta obra, preferindo defini-la como 'relatório'.

A citação de Prince de Ligne, memorialista do século XVIII, utilizada na epígrafe soa como um aviso: diz que o imperador Frédéric II, ao ter em mãos uma obra de Diderot, leu que o autor a dedicava aos jovens. $\mathrm{O}$ imperador teria fechado o livro imediatamente, sabendo que ela não lhe dizia respeito. A escolha dessa citação por Grégoire parece indicar tanto um campo de interesse, o memorialismo, como um 'público-alvo': os jovens, ou ainda a expectativa de alguma condescendência por parte do leitor diante dessa obra inaugural. Publicado em 2002, o livro recebeu no mesmo ano o prêmio Flore.

Aquele que ultrapassa a epígrafe e aceita o jogo proposto pelo autor, descobre que a ironia ali tem gosto amargo e funciona como um desvio do trágico: se na vida o autor não tem controle sobre os acontecimentos, no livro seu discurso é moderado. O leitor deve estar preparado para muito movimento e algumas

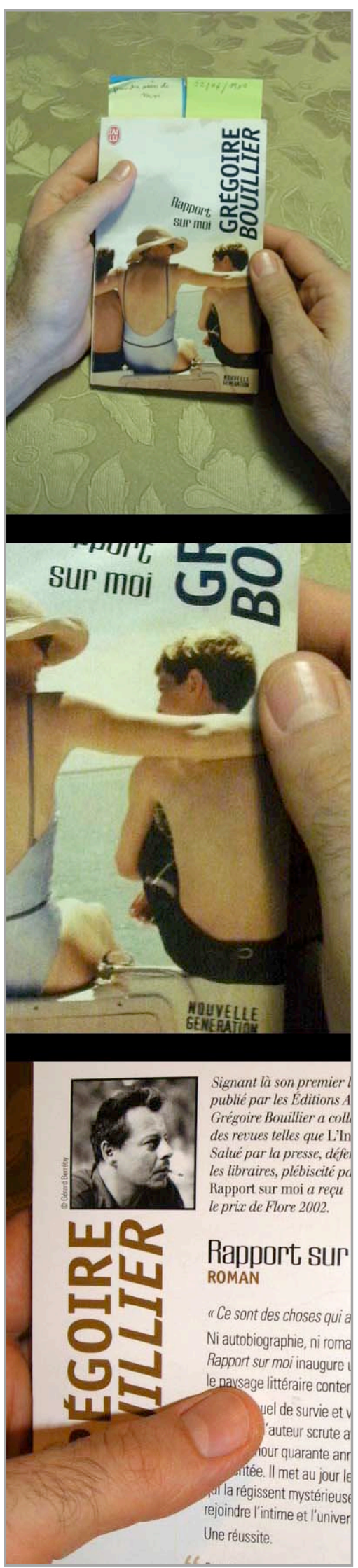


turbulências. O incipit é taxativo: “Eu vivi uma infância feliz”. Essa 'alegria' tem um significado muito próprio para Grégoire e assinala um primeiro desvio do que significaria para ele 'um lar feliz': após o parágrafo inicial de frase única, Grégoire relembra um momento da infância em que ele e o irmão brincam no quarto quando a mãe entra, pergunta a eles se a amam, e vai à direção da janela para se jogar. O livro está apenas começando e, por ora, a tragédia familiar só se insinua.

$\mathrm{O}$ autor divide as cento e vinte e sete páginas do livro em vinte segmentos não numerados que buscam cobrir, sempre aos saltos, os quarenta anos de sua existência. Na maior parte das vezes o autor parte de um determinado momento de sua infância/adolescência para avançar no tempo e contar algum fato mais recente.

O primeiro segmento do livro serve como introdução da narrativa e trata de pontuar alguns conflitos e apresentar os membros da família: a mãe, o pai, o irmão e o próprio autor. É a partir do segundo segmento que uma cronologia do autor começa a ser montada: ele nasceu no dia 22 de junho de 1960 em Tizi-Ouzou, capital da Grande Cabília (Argélia). Ele é o

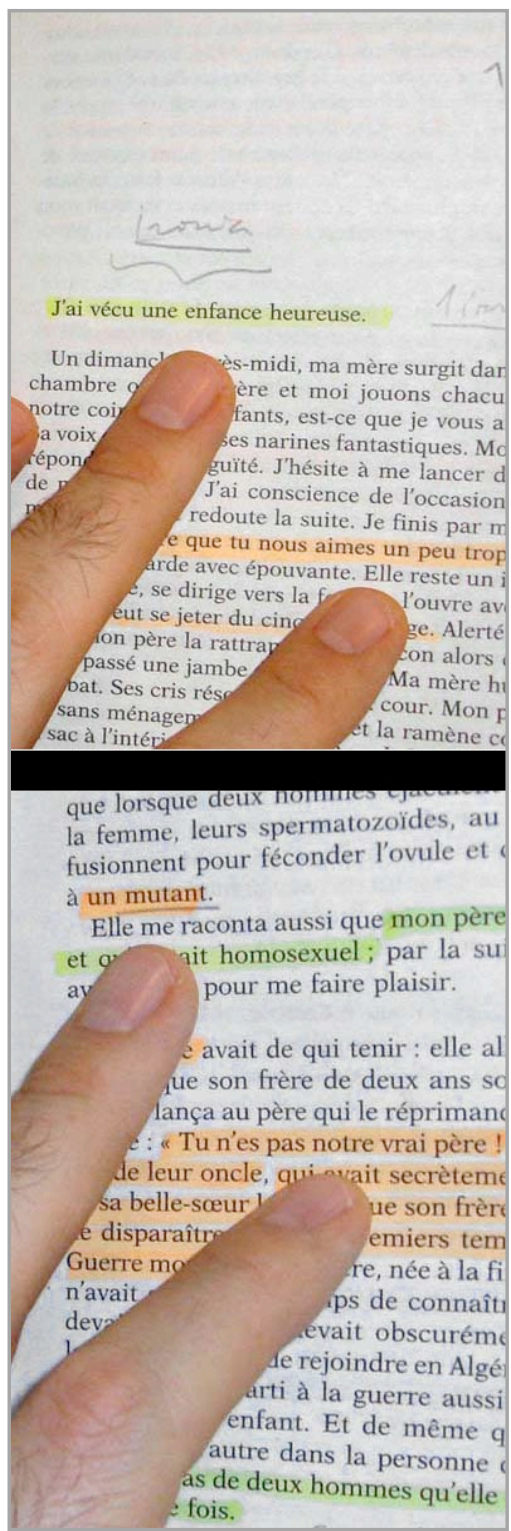
segundo filho da família - o primeiro havia sido deixado com os avós em Paris no momento que sua mãe partiu para a Argélia para se encontrar com o marido, que cumpria ali suas obrigações com o serviço militar.

Até o fim do terceiro segmento, a narrativa se fixa na primeira infância do autor e a história segue um ritmo lento: todo o relato é a repetição das histórias contadas pelos pais, que Grégoire aceita como reais dizendo: suas versões nunca variavam. É a partir do quarto segmento que começam os saltos temporais/espaciais que quebram a expectativa de um relato cronológico sugerido nos segmentos anteriores. Nesse momento, Grégoire conta que aos quatro anos de idade foi acometido de uma doença contagiosa grave - esse é o trampolim para que ele avance vinte e cinco anos e comece a falar do relacionamento 'virulento' com Laurence, a mulher com quem viveu durante sete anos e que é a mãe de sua única filha.

A velocidade dos acontecimentos narrados e a imprevisibilidade das conexões entre eles podem ser tidas como análogas a duas referências importantes para o autor. Num batepapo com internautas (BOUILLIER, 2006), Grégoire afirma que considera a literatura como uma partida de rúgbi - em oposição a Leiris, que relacionava a literatura à tauromaquia - e que entre seus autores preferidos estariam os cantores de rock, já que quase nenhum escritor francês lhe interessaria.

Se as incompatibilidades do autor, a agressividade dos seus envolvimentos amorosos e os 'desvios de conduta' em sua 
família podem ser identificados com o universo do rock — trilha sonora igualmente mutante —, a analogia com o jogo de rúgbi — disputa masculina agressiva em torno de uma bola ovoide - está na maneira como o autor expõe seus conflitos internos e suas disputas: ora avançando, abrindo espaço, agindo no ataque, ora recuando, se protegendo ou se lamentando. Os saltos temporais são como chutes que lançam a bola/história para outras instâncias.

Os momentos de avanço (ataque) são mais evidentes quando Grégoire trata da sua relação com as mulheres, principalmente quando faz notar o que há de excessivo e pernicioso na relação: os descontroles da mãe (amantes, abortos, tentativas de suicídio, o tratamento desigual com os filhos, etc.); a paixão alucinada por Laurence e as discordâncias intransponíveis que resultavam em rupturas e reatamentos entremeados por infidelidades e agressões físicas; a vidinha boêmia com Gaëlle, usuária de drogas; o ciúme doentio por Fabienne, sua fuga para os Estados Unidos e a viagem alucinada do casal a bordo de um Buick Skylark azul metalizado.

Se comparadas com a posição combativa e agressiva assumidas por Grégoire, as atitudes adotadas pelo pai e pelo irmão ao longo da narrativa são descritas pelo autor como medrosas e enigmáticas. $\mathrm{O}$ autor não reserva muito espaço para o pai - que aparece à sombra da mãe, acatando suas decisões e se movendo em silêncio para ajudá-la a se salvar das várias crises de depressão. Em dois momentos Grégoire fala de acontecimentos marcantes na vida do pai, o tom é triste e magoado: no primeiro, Grégoire conta que seu pai teria deixado de tocar bateria numa banda de jazz para receber uma ajuda financeira do avô de Grégoire no início da vida de casado; no segundo, o pai troca a família por outra mulher e, depois de um ano, volta para casa endividado e ameaçado de prisão. Já com o irmão o distanciamento teria sempre ocorrido, com o próprio Grégoire afirmando que sempre fora o preferido de sua mãe ${ }^{2}$. Deslocado na família e tendo vivido as turbulências adolescentes durante um intercâmbio nos Estados Unidos, o irmão não se adapta mais à vida da família Bouillier e faz o possível para

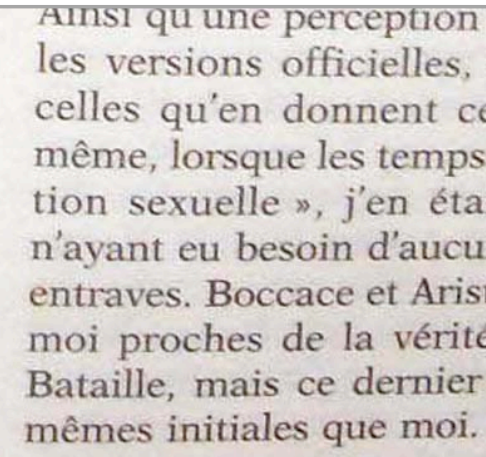

Sur le livret de famille d je suis né le 22 juin 1960.

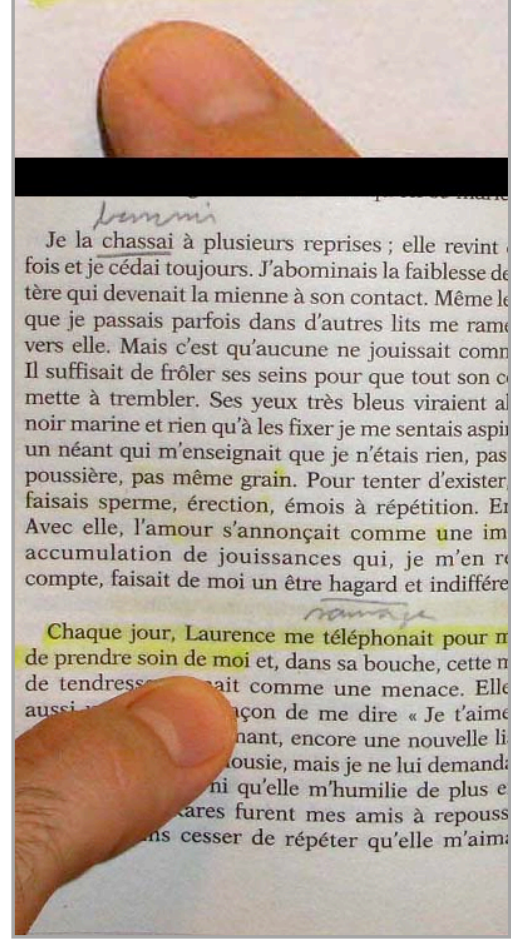
voltar aos Estados Unidos. Lá, ele se envolve com a prostituição, assume a homossexualidade e aceita todo tipo de serviço até se estabilizar como disc-jockey e vendedor de CDs em São Francisco.

\footnotetext{
${ }^{2}$ A foto da capa representa bem o sentido dessa 'desigualdade': abraçada a uma criança, a mulher sorri para outra.
} 
$\mathrm{O}$ que acontece com o pai e o irmão reverbera nas atitudes de Grégoire: além de buscar o afastamento dos pais, ele também abdica da sua paixão inicial — a pintura — dizendo que esse foi seu 'sacrifício para continuar a viver'. Da mesma maneira que o pai, ele também é 'readmitido' pela família depois de um período de errância. Ainda pensando na narrativa de Grégoire como um jogo de rúgbi, a sua

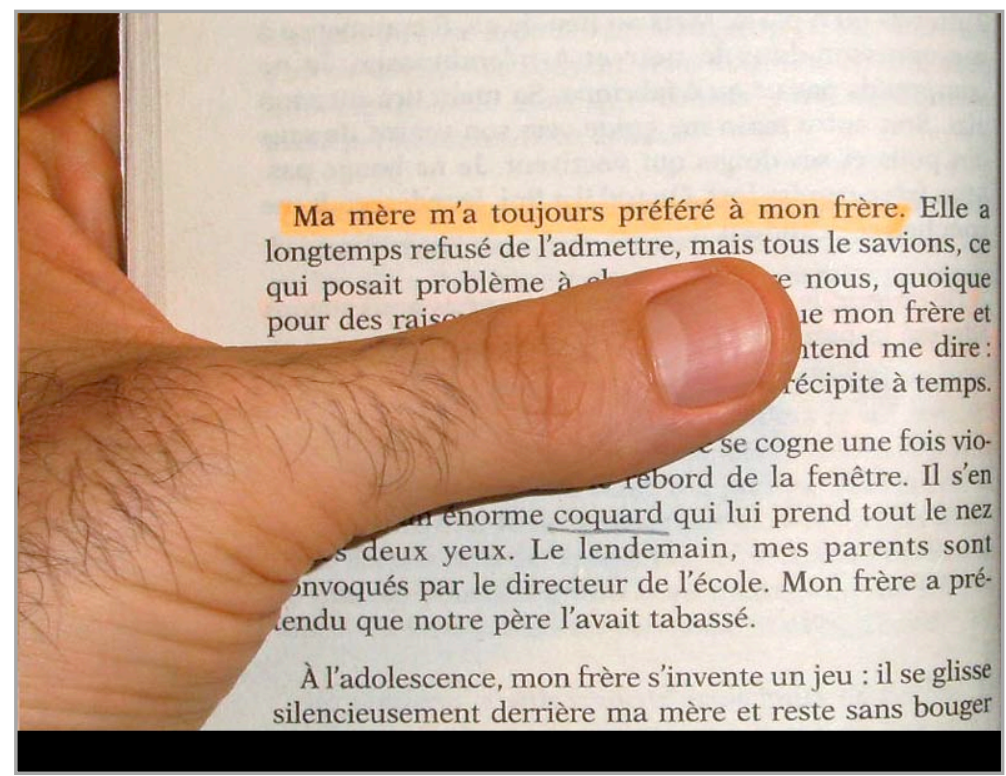
ons vécu pas même un regard, rien, pour ne p. réapparaître ni donner aucune nouvelle penda Un chef-d'œuvre de disparition ! I f fallut presqu ner. Le lendemain, mes cheveux avaient bla côté. Je n'en revenais pas. Quel flair était don moi l'anosmique, pour avoir élu parmi la multi capable de reproduire la disparition de $\mathrm{Mm}$ qui, quinze ans auparavant, paraissait pourt: passable? L'histoire se répète de manière car ricanais-je tout haut dans les rues. Avant de m c'est peut-être la répétition qui fait l'histoire.

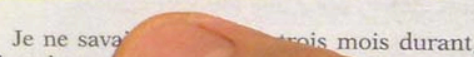
Je ne sava tmis mois durant dans la rue me versaier j'étais, dorm connaissais pha connaissait. Pour tout le temps des volx gauche, ou à droite, de march car un cheval avait poussé une immense le corps d'un cheval).

Les voix n'étaient pas méchantes ; mais el ordonné d'assassiner des inconnus ou de ainda não entendia que trajeto era esse.

A recuperação de Grégoire se deu aos 40 anos quando, para iniciar uma 'nova vida', ele decidiu recompor seu passado tomando por 'guia' a Odisséia, de Homero — esse grande poema épico que trata da viagem de Ulisses de volta para casa. Para ele, essa obra — lida nas entrelinhas — permitiu que ele reconhecesse um valor mitológico a tudo o que havia se passado com ele até então.

$\mathrm{Na}$ entrevista que deu pouco antes de vir ao Brasil para participar da FLIP/2009 (CHAVES, 2009), o autor justifica a necessidade de tomar suas experiências pessoais como fonte para aquilo que escreve porque acredita que, de outro modo, elas se perderiam: a escrita organizaria a turbulência das suas vivências permitindo comunicá-las, contribuindo de alguma maneira para a compreensão daquilo que o leitor também vive. No chat com internautas (BOUILLER, 2006), o autor afirma escrever ficções — mas 'ficções que estão no coração da

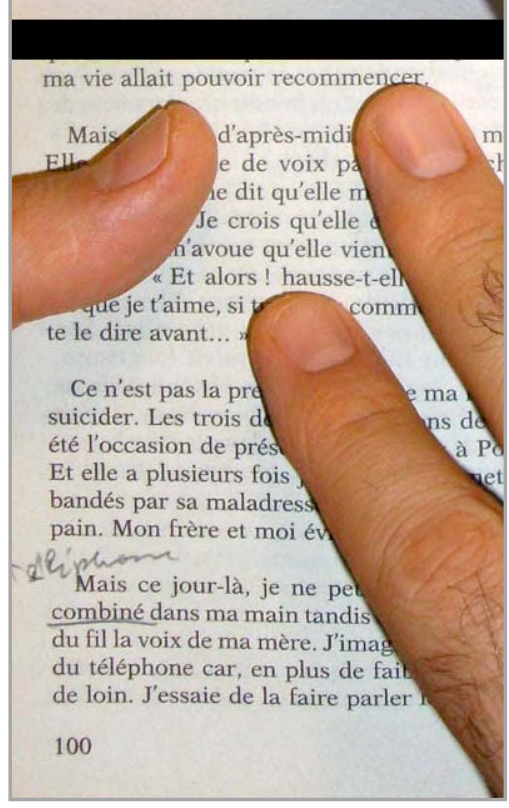


realidade' — e que em Rapport sur moi tudo o que é contado teria realmente acontecido. Assim, o 'relatório' (rapport) do título, definiria um novo gênero literário por limitar a narrativa à 'ação de contar apenas o que se viu e ouviu'. Talvez isso ainda seja muito pouco para, como pretende o autor, definir uma maneira especial de configurar vivências particulares em literatura. Nesta obra, o texto de Grégoire não difere em nada da 'autobiografia' tradicional, principalmente porque seu texto é convencional na forma e muito limitado na expressão: nada ali define um tempo especial compartilhado e a linguagem não acompanha o desarranjo, os atritos ou a exacerbação das experiências vividas. O 'relatório' do título parece então significar uma 'maneira literária aplainada' de contar histórias onde o 'mutante' da vida real se ajusta e se normaliza. A vida alucinada do autor ganha forma de relatório, não porque corresponda à verdade do olhar de quem testemunha, mas porque preenche os protocolos de construção de uma história que, a qualquer custo, tem que fazer sentido.

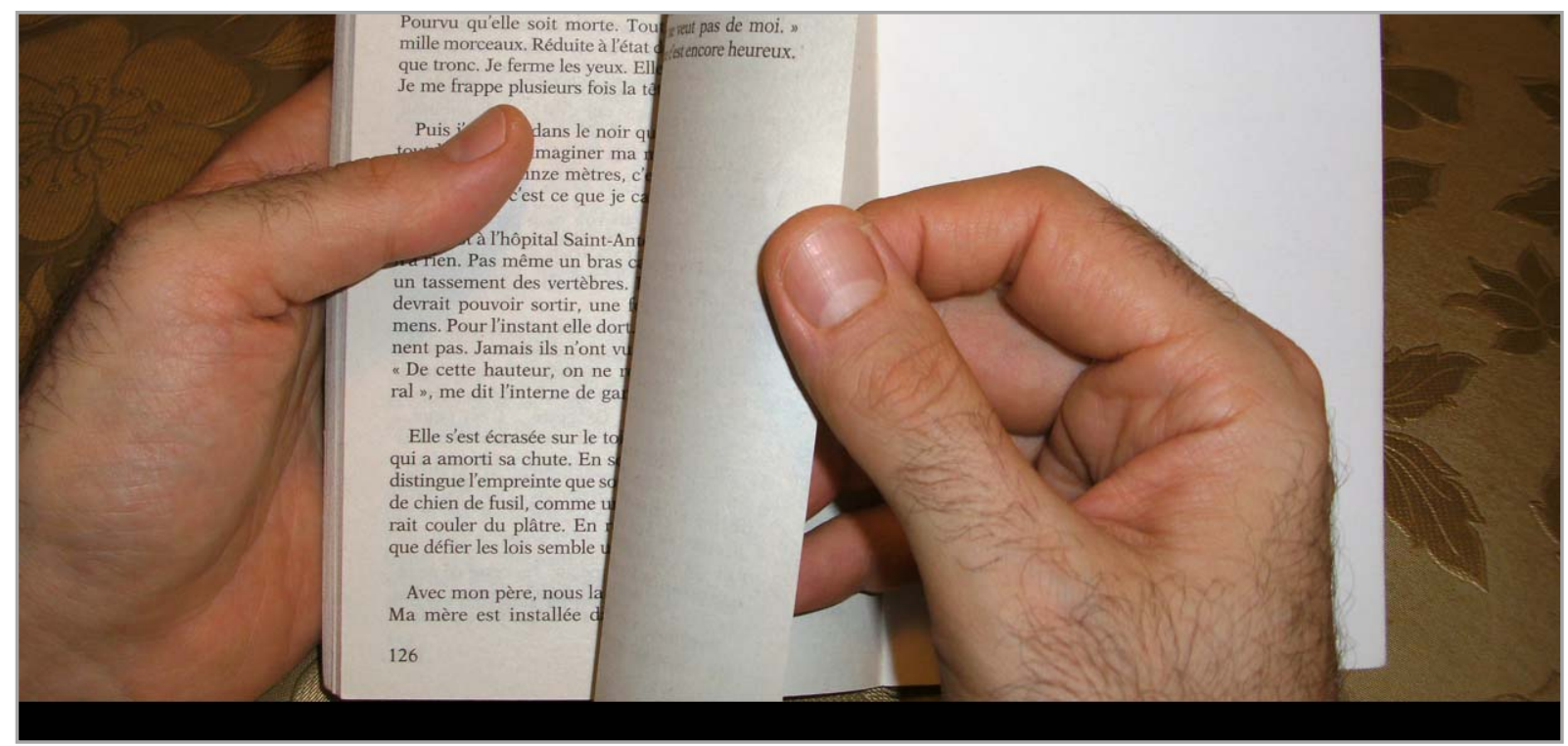

\section{Referências bibliográficas}

BOUILLIER, Grégoire. On a aucun moyen de vérifier la netteté du monde. Grégoire Bouillier en Chat. L'Internaute. Magazine. Avril 2006. Disponível em:

<http://www.linternaute.com/sortir/auteurs/gregoire-bouillier/gregoire-bouillierretranscription.shtml>. Acesso em: 30 de jan. 2010.

CHAVES, Teresa. Francês que vem à Flip rechaça a ficção como material literário. Entrevista com Grégoire Bouillier. Folha on-line. Ilustrada. 23/06/2009. Disponível em:

<http://www1.folha.uol.com.br/folha/ilustrada/ult90u585012.shtml>. Acesso em: 30 jan. 2010. 
Sophie Calle. Histórias Reais. (Título original Des Histoires Vraies.) Tradução de Hortência Santos Lencastre. Rio de Janeiro: Agir, 2009. 85 p.

\title{
A RECOMPOSIÇÃO SEM FIM DE UMA MITOLOGIA DE SI
}

\begin{abstract}
A capa de Histórias Reais é inquietante: é a fotografia de uma mulher que apoia o próprio seio na concha da mão, num gesto de quem oferece 'seu alimento' ao leitor. A visão incita o tato e o objeto demanda carícia - difícil não ceder a esse gesto generoso. Agora posso abrilo, desdobrá-lo e examinálo. Em algum momento a fantasia se rompe e só reconheço o nome da
\end{abstract}

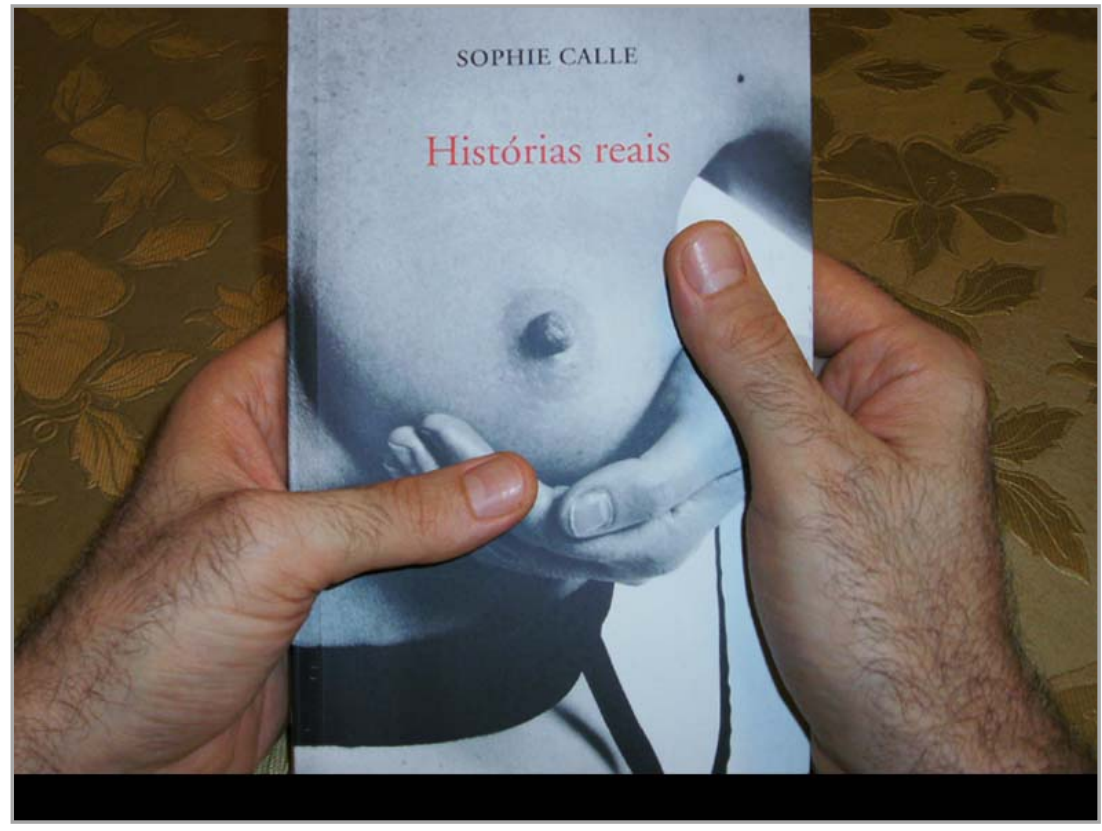
artista, a presença da fotografia do seio e o 'real' do título que encobrem um conjunto de narrativas documentadas que expõem com um pudor calculado a intimidade de uma mulher artista.

Já na epígrafe a artista conta que, após o rompimento de uma relação de sete anos com um homem, uma amiga resolveu ajudá-la pedindo o endereço de um desconhecido encontrado num bar, para dar a ela de presente. Sophie Calle dedica seu livro a esse desconhecido por aquilo que esse encontro gerou de romanesco na sua vida. Aí estão alguns elementos que são recorrentes nas narrativas da artista: o relato autobiográfico; a exploração da ausência; o exercício do inusitado; a produção do romanesco; e, por fim, o anonimato dos agentes.

Este é o primeiro livro de Sophie Calle publicado no Brasil. Como parte de uma produção ligada aos desdobramentos da Arte Conceitual, 'Histórias Reais' necessita de informações complementares para uma compreensão mais justa daquilo que a artista nos propõe.

O livro é composto por 38 histórias que seguem a mesma estrutura: possuem um título, uma micronarrativa e uma fotografia distribuídos numa página dupla. Cada uma dessas histórias estruturadas como acabei de expor — é um 'trabalho' que, na maioria das vezes, faz parte de uma série. Todos os trabalhos foram feitos entre 1988 e 2003 e foram chamados pela artista de 'Autobiografias' ${ }^{3}$. A

\footnotetext{
${ }^{3}$ Essa informação não consta no livro e só fica evidente no catálogo da Retrospectiva dessa artista apresentada em 2003 em Paris. Cf. Sophie Calle: M'as-tu vue. Catalogue. Paris: Centre Pompidou / Xavier Barral, 2003.
} 
não ser pela única série incluída no livro: 'O marido - 10 histórias', nenhuma das outras 28 histórias está numerada ou tem identificada a série da qual faz parte. No livro não constam informações sobre a artista ou qualquer dado técnico dos trabalhos (ano, nome da série, dimensões, locais onde foram expostos, etc.). Para aqueles que conhecem um espectro maior da sua obra, Histórias Reais representa uma antologia da sua produção, com temas, procedimentos, estruturas e rituais que definem os vários papéis que ela assume no contexto da sua produção: autora, narradora, personagem e performer. Já, para o leitor iniciante desse universo, concentrado no sentido imanente das narrativas, Histórias Reais deve ser tomado como um álbum sentimental da artista feito de lembranças e rituais recompostos por meio dos seus depoimentos e de fotografias.

Em Histórias Reais, a artista é a narradora e a personagem principal das narrativas, que sempre se referem a um acontecimento vivido por ela no passado. O livro compõe por si só um ritual de rememoração que inclui vários tipos de rituais. Em 'O sapato vermelho', por exemplo, a artista conta que quando tinha 11 anos, saía com uma amiga toda quinta-feira à tarde para visitar as grandes lojas de departamento para roubar alguma coisa. O 'sapato vermelho' do título, cuja fotografia acompanha a narrativa, foi o produto do último roubo da dupla. Em outra história, 'A gravata', a artista fala um ritual iniciado em 1985 e que perdurava ainda em 1992: ela esteve numa conferência onde o palestrante usava uma gravata que ela considerou muito pouco elegante. Acreditando que poderia contribuir no melhoramento da aparência desse desconhecido, ela enviou para ele uma gravata nova de presente. Ao rever o mesmo homem em outra situação, ela viu que não bastava trocar apenas a gravata e, a partir de então, sempre no Natal, ela passou a presenteá-lo com uma peça de roupa diferente por $\mathrm{ano}^{4}$. A fotografia que acompanha a narrativa apresenta uma gravata escura sobre fundo claro.

A exploração da ausência é um tema dominante na produção da artista e, dependendo do trabalho, se apresenta sob diferentes aspectos: solidão, desaparecimento, escondimento, abandono, perda, roubo, morte ou esquecimento. Isso está marcado em boa parte do livro por histórias que dão destaque a momentos, objetos e lugares que, por alguma razão, designam aquilo que, no momento da narrativa, é perdido ou inalcançável. O primeiro marcador da ausência presente nas histórias é aquele que trata do momento vivido: ao definir a idade que ela tinha ou o ano

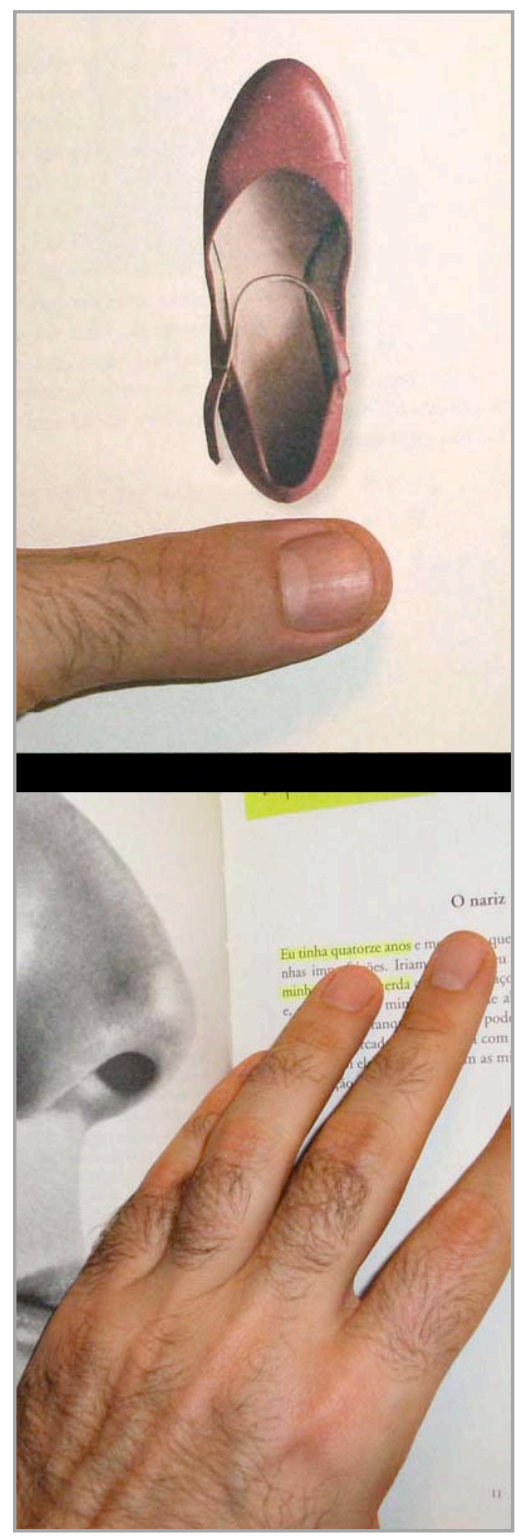

\footnotetext{
${ }^{4}$ Essa história faz parte da série "La garde-robe". In: Sophie Calle. Les panoplies (Livre III). Doublé-Jeux. Arles: Actes Sud, 1998.
} 
em que a história se passou, a artista reafirma a perda da juventude e a impossibilidade de recuperar esse momento vivido, se dedicando então a recompô-lo. Outro marcador importante nas histórias é a presença de um objeto particular. Em 'O roupão', por exemplo, ela conta que quando tinha dezoito anos, seu primeiro amante, para corresponder ao seu desejo, costumava vestir um roupão branco todas as manhãs para evitar que ela o visse nu, de frente. Depois da sua partida, restou a ela o roupão. A fotografia que acompanha o texto mostra exatamente esse objeto pendurado na parede: isolado, imóvel e mole, é a própria imagem do abandono e da solidão.

Em Histórias Reais, a ambiguidade se apresenta em maior grau na maneira como a artista confronta a relação de cada história com a palavra 'real' incluída no título do livro. Inicialmente, a presença da fotografia no âmbito de cada história poderia creditá-la como traço do real/verdadeiro daquilo que é narrado, mas não é o que acontece na maior parte das vezes e essas imagens devem ser tomadas como 'encenações fotográficas' (o que mantém a relação das imagens com o real, mas enfraquece o grau de veracidade das histórias). Nesse álbum sentimental, reconheço ao menos quatro ordens distintas para essas encenações: como reconstituição de um fato ocorrido, como documento que justifica a história, como ilustração da narrativa e como fantasia do tema abordado.

Como exemplo de reconstituição de um fato ocorrido, assinalo a história 'Sonho de moça' (p. 12-13): aí, a artista conta que quando tinha quinze anos tinha medo dos homens e que, ao ir a um

Nada - ninguém

n 1984. Uma desconhecida, chamada ne para ir ao apartamento onde mora aram" e que morreram ali, com seis mes anos. Mâkhi herdou suas roupas, ma I aquela visita a um lugar assombrado - e seus fantasmas. Entāo, fui no lugar onada, para the oferecer imagens daqu edi para ficar com o retrato delas e com enda de 1980, no dia 25 de dezembro, - ninguém"; e em 1981: "Natal - nada
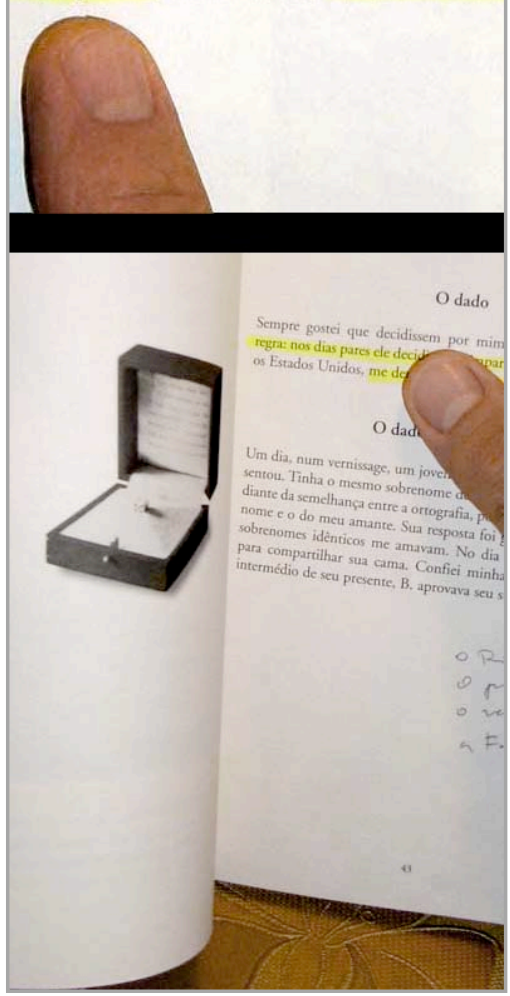
restaurante, pediu uma sobremesa chamada "Sonho de Moça".

Quando perguntou ao garçom o que era, este disse ser uma surpresa e, minutos depois, ao trazer para ela um prato com duas bolas de sorvete de creme e uma banana, desejou a ela bom apetite. Ela conteve as lágrimas e fechou os olhos, da mesma maneira como faria anos depois quando viu um homem nu pela primeira vez. A fotografia que acompanha a narrativa mostra, numa vista de topo, uma travessa oval, clara e extremamente limpa com duas bolas de sorvete na parte superior da imagem e uma banana, na vertical, logo abaixo das bolas de sorvete — não resta qualquer dúvida que se trata de uma metáfora dos genitais masculinos. Se o sentido inicial que liga o título da história à fotografia é grosseiro e vulgar, a narrativa justifica, suaviza e sentimentaliza essa relação. A fotografia se apresenta como reconstituição porque corresponde exatamente ao que é descrito no texto e mostra indícios de que a composição da imagem é artificial (nada no relato faz supor na possibilidade da artista, aos quinze anos, ter pensado em fotografar uma sobremesa antes de comê-la).

Já a fotografia como documento que justifica a história aparece em 'A lâmina de barbear' (p. 20 - 21). Nesse trabalho, a artista conta que na época em que posava nua havia um homem que, sempre que 
desenhava seu corpo, concluía cortando o desenho com uma gilete e jogando fora os pedaços antes de ir embora. Isso aconteceu durante doze sessões, até que na décima terceira vez a artista não foi trabalhar. A fotografia que acompanha a narrativa não é reconhecida como uma 'fotografia', mas como a reprodução fotográfica de um desenho da artista nua, cortado em vários lugares e com marcas da fita adesiva que fecha os cortes. O suporte fotográfico desaparece para dar lugar à impressão de que é o próprio documento descrito na narrativa que está ali.

A fotografia como ilustração da narrativa pode ser reconhecida na história 'O vestido de noiva' (p. 28-29). Aí, a artista conta que admirava muito um homem desde criança. Quando ela tinha trinta anos ele aceitou recebê-la em casa. Para essa viagem, a artista providenciou um vestido de noiva de seda branca com uma pequena cauda que ela usou em sua primeira noite de amor com ele. Numa vista de topo, a fotografia exibe apenas dois elementos: um vestido claro sobre o que parece ser um lençol recentemente desdobrado. A fotografia repete o título da história e se justifica pelo conteúdo da narrativa. Nada na imagem ou no texto permite caracterizar o vestido fotografado como sendo exatamente aquele utilizado no evento descrito, servindo apenas como um reforçador para o que a artista nos conta.

A fotografia como fantasia do tema abordado pode ser vista em 'Os gatos' (p. 24-25). Nessa história a artista conta que teve três gatos: Félix, Zoe e Nina. Cada um deles teve um fim diferente: o primeiro morreu preso na geladeira, o segundo foi tirado da artista quando nasceu seu irmão e o terceiro foi estrangulado por um amante ciumento que havia imposto uma condição para continuar com a artista: ou ele, ou o gato. A artista escolheu o gato. A fotografia que acompanha a história é a reprodução tripla de uma mesma imagem: uma vista de topo dos restos de um gato em estado avançado de putrefação sobre um piso áspero de sulcos retangulares. Além de não ser possível

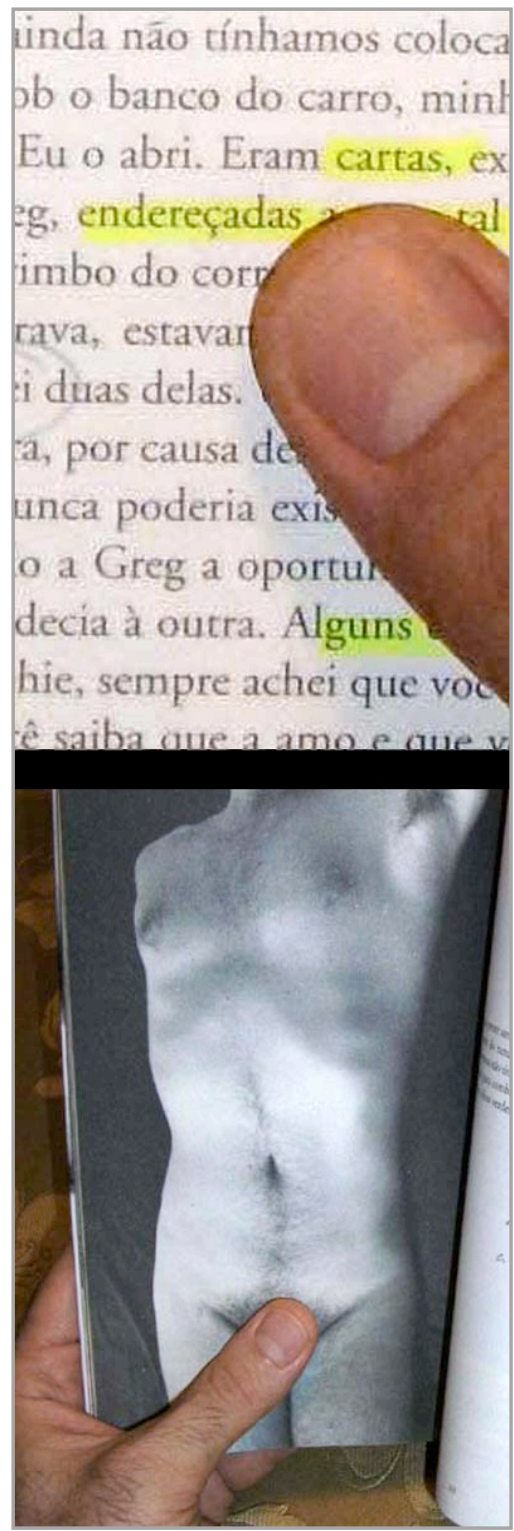
reconhecer qualquer indício de que os restos do único gato fotografado correspondam a qualquer um dos três gatos da artista, a repetição da mesma imagem só exacerba triplamente as perdas sofridas pela artista.

No contato inicial com a obra dessa artista, pode surgir um primeiro incômodo pela fragilidade dos meios: a estrutura (título/texto/fotografia) é simples e repetitiva, o texto parece raso e desinteressante e as fotos, com exceção daquelas que retratam a artista e expõe grande teatralidade, sugerem apenas uma duplicação do sentido literal do texto ao lado. Acreditar que Sophie Calle seja uma 'fotógrafa que escreve' ou uma 'escritora que fotografa' também não se justifica porque ela não se 
sobressai em nenhum dos campos: no âmbito da sua produção, texto e imagem não são estradas paralelas, mas um caminho único com duas faixas. Sophie Calle então não é nem escritora, nem fotógrafa, sua 'marca', diz ela para Colard (2008, p. 33), está na 'natureza da história'. A artista então não é 'fotógrafa' no sentido daquela que 'tira fotografias' mas no sentido daquela que 'concebe imagens' e propõe 'encenações fotográficas' ${ }^{\text {' }}$ A artista também não é escritora porque, além de fazer uso de depoimentos e entrevistas, ela não explora a palavra com autonomia, seu texto está sempre atrelado à materialidade de uma imagem externa a ele (que pode ser uma fotografia, mas também um objeto ou um espaço). O exercício da artista com a palavra e a fotografia é então o de 'enxugar' ao máximo os meios para rebaixá-los ao nível da objetividade e da neutralidade 6 . Ao limitar ao máximo os elementos que compõe a imagem fotografada, isolando objetos ou optando por um fundo neutro, e ao condensar ao

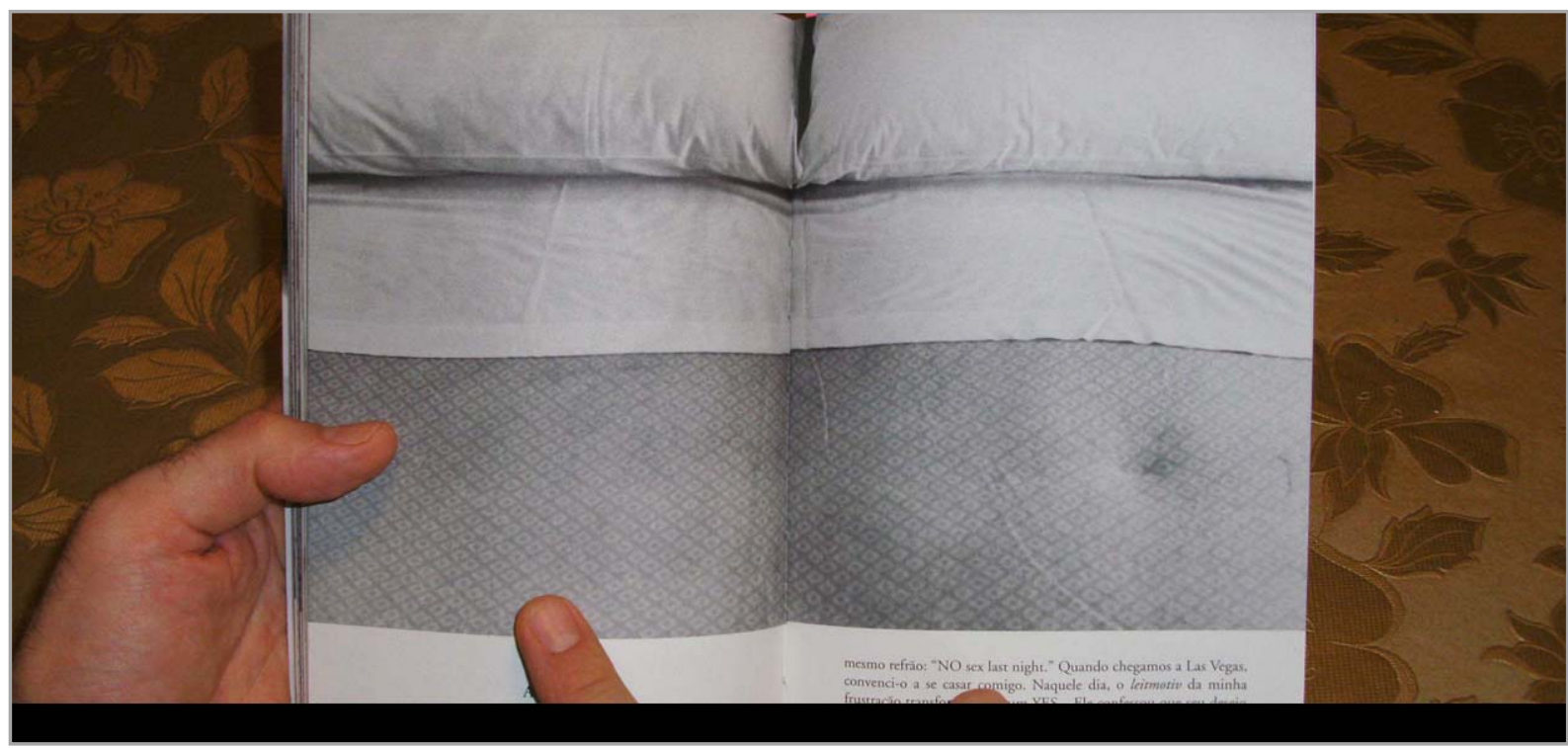

máximo os textos, a artista aproxima os dois meios da superficialidade e da artificialidade. É nesse nível que a artista unifica seu discurso.

Um questionamento frequente que acompanha sua obra, diz respeito à veracidade dos seus relatos. Na entrevista com Mariana Shirai (2009), a artista diz que o objetivo em Histórias Reais é tratar do 'artístico' e não da 'verdade'. Mesmo que todas as histórias tenham acontecido, afirma a artista, nada ali seria verdade porque isso seria impossível: o simples recorte, o ponto de vista adotado e o vocabulário bastariam para confirmar o resultado desse esforço como um movimento deslocado da vida.

\footnotetext{
${ }^{5}$ Isso nunca aparece de forma explícita em seus trabalhos: na última página de 'Histórias Reais' a artista agradece a Jean-Baptiste Mondino — 'autor discreto e generoso de algumas fotografias deste livro' (negrito nosso). Quais são essas fotos? A única fotografia identificada como sendo de Mondino é a que acompanha a história 'Os seios milagrosos' — a mesma que está na capa, constando, portanto, das especificações editoriais da edição brasileira.

${ }^{6}$ A neutralidade desses dois meios não significa nem uma limitação técnica, nem um empobrecimento do uso da língua. Quanto ao texto, o leitor da tradução em português não se dá conta das nuances do uso da língua francesa. Exemplo disso é a mudança de registro operado pela artista quando esta emprega o passé simple (tempo verbal literário) em uma das histórias: 'O vestido de noiva'. Cf. Robert Storr. Sophie Calle, la femme qui n'était pas là. Dossier Photographie: fait et fiction. In: Artpress, n 295, nov. 2003. p. 23.
} 
A artista afirma que seus estímulos são verdadeiros e que seu esforço criativo é um tipo de abordagem positiva às frustrações pessoais (COLARD, 2008, p. 30): é por meio da obra realizada que ela pode expor o esforço depreendido na superação de uma dor. Não se pode dizer que Sophie Calle sofra para fazer arte, mas, reservando suas felicidades para o âmbito pessoal, ela utiliza suas tristezas como ações mobilizadoras da sua produção artística.

O que amplia a ambiguidade de sua obra é que a artista não fala de si apenas no contexto da obra, ela também se multiplica em outras figuras que relatam a vida vivida à custa da primeira em novas configurações das mesmas histórias, com outros títulos, com outros arranjos, em outros espaços. Ao invés de ampliar uma biografia, a fala de cada duplicação da artista subtrai algo ou agrega uma informação nova às histórias sabidas, embaralhando as cartas de um jogo que a artista nunca deixa de jogar com seu público. A intimidade revelada na obra é calculada e o decoro assegurado. Por tudo isso, penso Histórias Reais, não como uma autobiografia, mas como o álbum de uma mutante que constrói, a

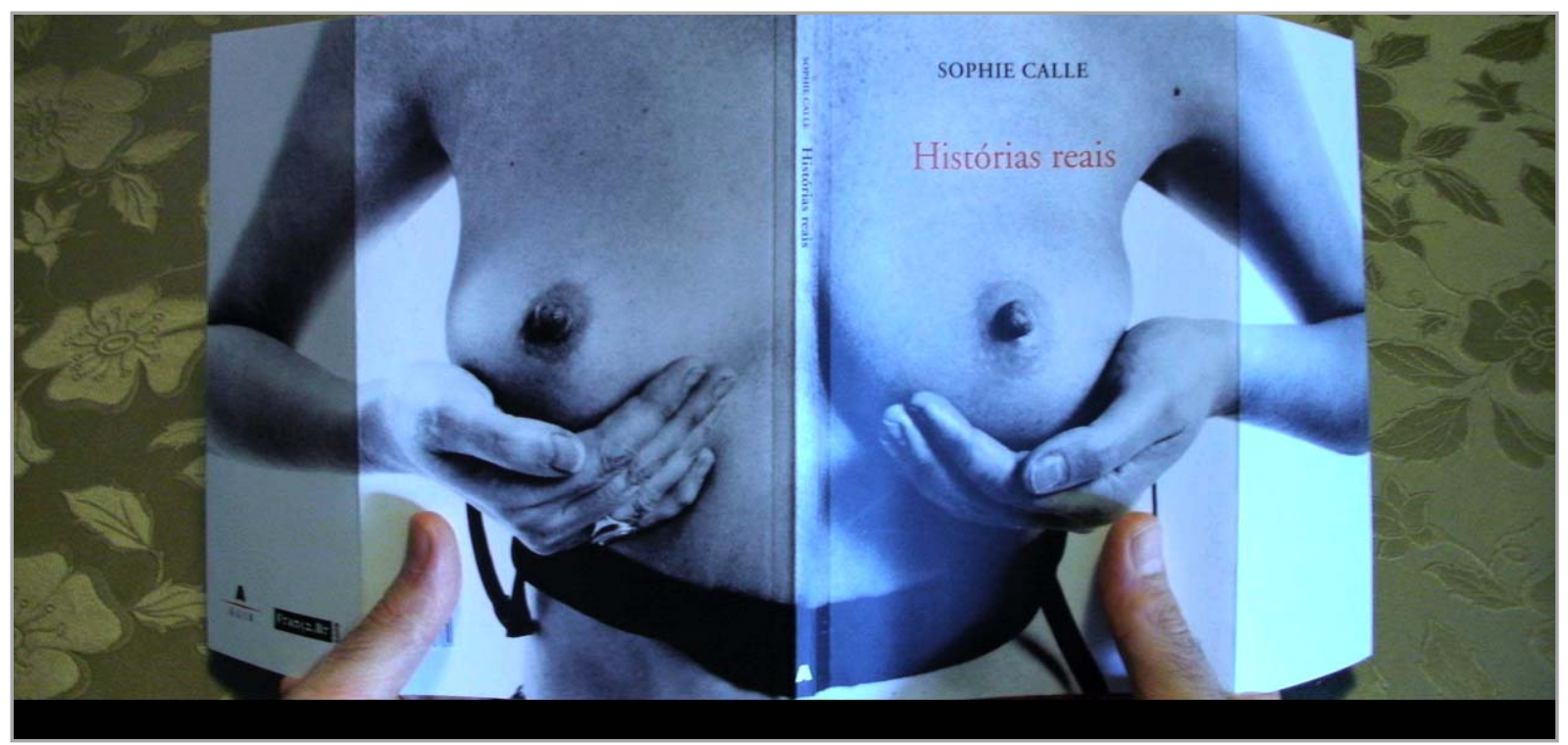

cada trabalho, uma mitologia que se alarga, se desdobra, até que, de repente, começa a rasgar.

\section{Referências bibliográficas}

COLARD, J.-M. Entretien Sophie Calle. Les Inrockuptibles, n n 643, 25 mars 2008.

SHIRAI, Mariana. Não estou expondo minha vida, mas uma carta de despedida como outra qualquer.

Entrevista com Sophie Calle. Revista Época. 05 jul. 2009. Disponível em:

$<$ http://revistaepoca.globo.com/Revista/Epoca/0,,EMI80640-15220,00.html>. Acesso em: 15 jul. 2009. 
Édouard Levé. Autoportrait. Paris: POL, 2008. 125p.

\section{A IMPRESSÃO DE UM CÉREBRO ANTES QUE TUDO TERMINE}

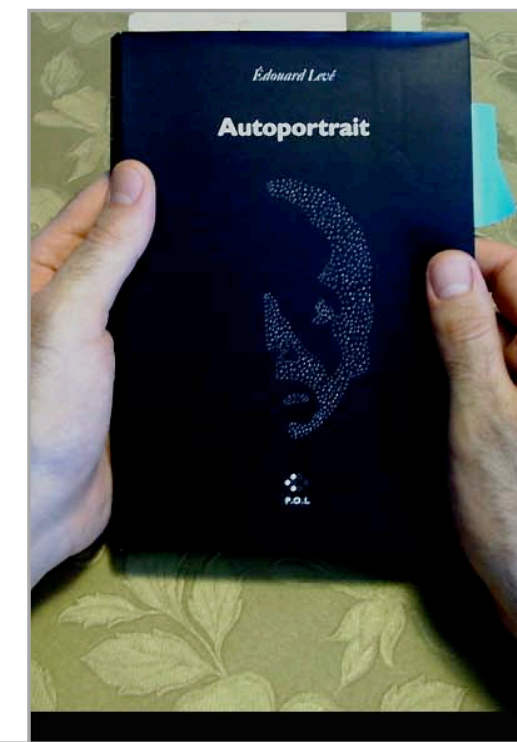

ambiguidade começa pelo paradoxo sugerido no título: o autorretrato, uma representação imagética (normalmente executada como desenho, pintura, ou fotografia) é realizado por Levé através de um texto em primeira pessoa que, num fluxo de consciência, ocupa um único parágrafo ao longo de 125 páginas. $\mathrm{O}$ autor tem consciência da inconveniência daquilo que propõe quando conta que, apesar de já ter publicado dois livros com seu editor, este continua a chamá-lo de 'artista' e não de 'escritor'.

Este livro foi lançado em 2005 e é a terceira obra de uma carreira literária iniciada em 2002 com Euvres e seguida por Journal em 2004. Em 2002 e 2003 ele também publicou dois livros de fotografia que, pelo uso sistemático de contraintes (restrições), criam um estranhamento para quem pensa ver ali um ensaio fotográfico tradicional — sua obra é mais bem compreendida como produção da Arte Contemporânea com certa reverberação do trabalho efetuado pelo OuLiPo (Ouvroir de Littérature Potentielle).

O livro tem uma sobrecapa preta com um desenho de metade de um rosto feito por pontos brancos. Encobrindo o livro de capa branca e nenhuma imagem, a sobrecapa preta ganha um sentido de pele, ou ainda, de máscara. Mesmo que não apareça nos créditos do livro, é bem provável que o desenho da sobrecapa seja do próprio autor: artista autodidata e de múltiplos interesses que partiu da pintura para se fixar na fotografia e na literatura.

O paratexto que acompanha a edição faz crer que se trata

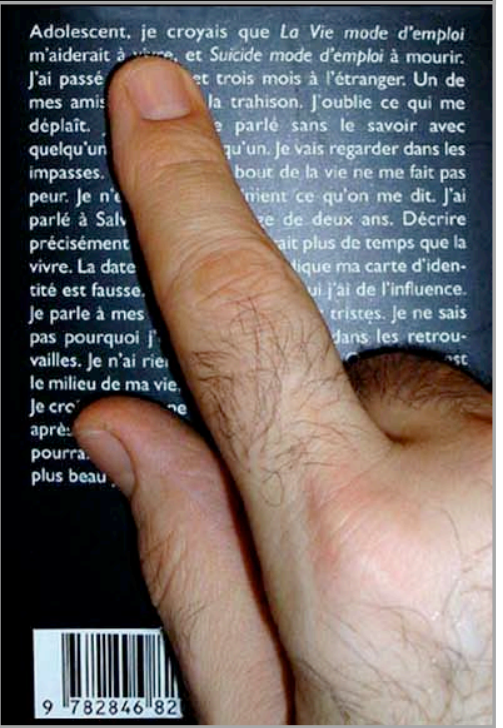


mesmo da obra de um escritor: na orelha da sobrecapa e na página 3 aparecem os títulos de outros quatro livros publicados pela P.O.L. e dois títulos publicados pela editora Philéas Fogg (sem nada que especifique o gênero ou conteúdo desses livros). Na quarta capa do livro e também na sobrecapa, como 'amostra' do que o leitor irá encontrar no livro, foi

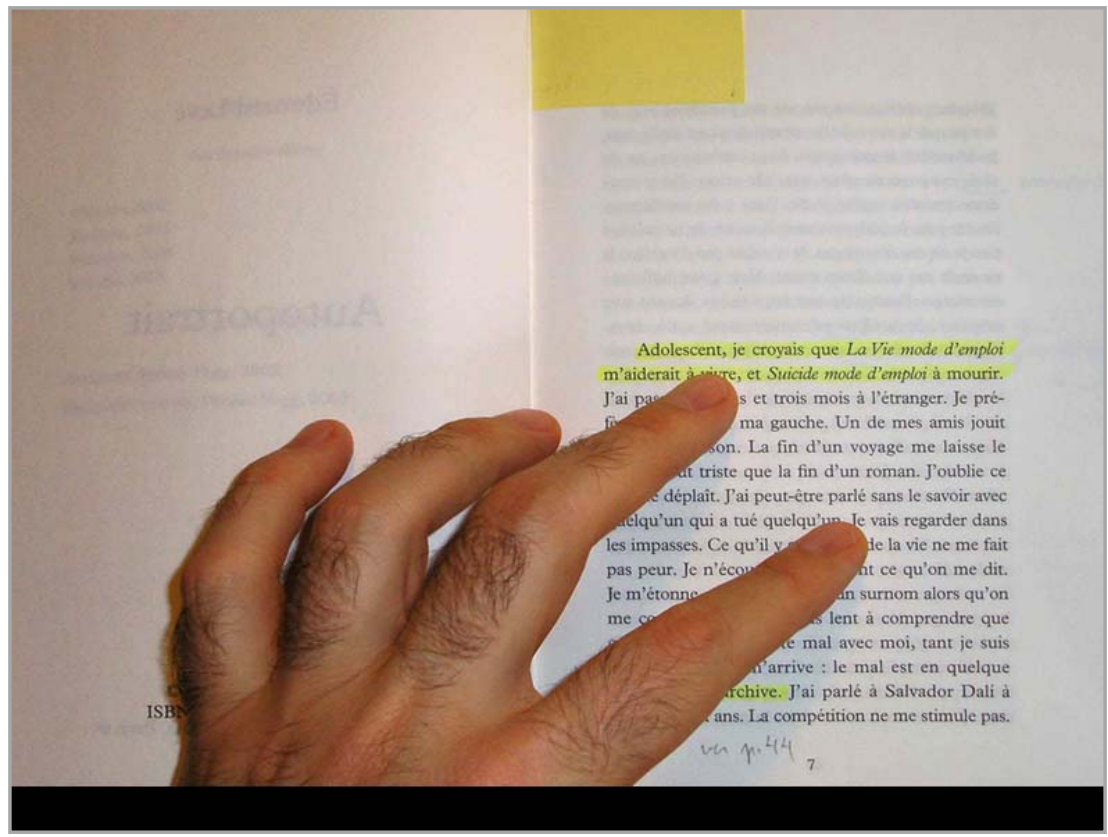
incluída uma 'colagem' do texto principal: num único parágrafo de vinte linhas aparecem, sem pudor, o incipit e o explicit, além de algumas frases da primeira e última página do livro: é uma 'imagem reduzida' do autorretrato em escala natural.

Duas referências literárias surgem logo no incipit: "Adolescent, je croyais que La Vie mode d'emploi m'aiderait à vivre, et Suicide mode d'emploi à mourir." (Adolescente, eu acreditava que A Vida modo de usar me ajudaria a viver, e Suicídio modo de usar a morrer) (p. 7). (negritos nossos). O autor faz uso da ironia ao comparar duas obras díspares: a primeira — La Vie mode d'emploi ${ }^{7}$ — é a grande realização romanesca de Georges Perec, e a segunda — Suicide mode d'emploi ${ }^{8}$ — é um levantamento histórico/teórico/prático sobre o suicídio. Além dos limites entre vida e morte sugeridos pelas obras citadas, também é necessário levar em conta aquilo que opõe suas naturezas: a fantasia — na forma da ficção — e a realidade — na forma do referente (o documento e a história).

Na composição do seu autorretrato, o autor se revela pelas escolhas que faz. Entre os autores e obras que mais lhe interessam estão: Raymond Roussel, Charles Baudelaire, Marcel Proust, Alain Robbe-Grillet, Antonio Tabucchi, André Breton, Olivier Cadiot, Jorge Luis Borges, Andy Warhol, Gertrude Stein, Ghérasim Luca, Georges Perec, Jacques Roubaud, Joe Brainard, Roberto Juarroz, Guy Debord, Fernando Pessoa, Jack Kerouac, La Rochefoucauld, Baltasar Gracian, Roland Barthes, Walt Whitman, Nathalie Quintane, la Bible, Bret Easton Ellis, etc. Mesmo com todos esses interesses, ele diz em outro momento do livro que não se sente sob a influência de qualquer escritor. Quanto a outros artistas e fotógrafos que admira estão: Douglas Huebler, Edward Ruscha (artistas contemporâneos ligados à Arte Conceitual e ao Livro de Artista) e Walker Evans, Diane Arbus, Steven Shore e Joel Sternfeld (fotógrafos).

\footnotetext{
${ }^{7}$ Georges Perec. A Vida modo de usar. São Paulo: Companhia das Letras, 2009.

${ }^{8}$ Claude Guillon; Yves Le Bonniec. Suicide, mode d'emploi : histoire, technique, actualité. Paris: Alain Moreau, 1982. Livro que alcançou um grande sucesso no seu lançamento, foi alvo de vários processos até ser proibido pelo governo francês de ser reimpresso e comercializado no território francês, acusado de propagar o suicídio.
} 
Através de uma entrevista dada em 2005 (MAURICE, 2007), sabemos que Édouard Levé escreveu Autoportrait enquanto viajava pelos Estados Unidos para executar um ensaio fotográfico: Amérique ${ }^{9}$. Esse ensaio foi feito a partir de uma contrainte que é descrita no próprio Autoportrait: fazer uma viagem pelos Estados Unidos para fotografar unicamente cidades homônimas de cidades importantes de outros países: Berlin, Florence, Oxford, Canton, Jéricho, Stockholm, Rio, Delhi, Amsterdam, Paris, Rome, Mexico, Syracuse, Lima, Versailles, Calcutta e Bagdad. Ele justifica esse tipo de procedimento em Autoportrait dizendo não ser da sua natureza fotografar ao acaso. Contraditoriamente, ele diz gostar de fazer coisas que são contrárias à sua natureza e, por isso, precisa inventar restrições para ter um álibi no enfrentamento da realidade (campo por excelência do imprevisível). Parece então que, para Édouard Levé, a restrição funciona não só como um limitador de ações, mas como uma máscara que permite ao artista se aproximar do real e do seu interlocutor, justificar seu desejo e explicar seu esforço sem precisar expor sentimentos, dúvidas ou qualquer outra subjetividade.

Jacques Maurice (2007) conta nessa mesma entrevista que, enquanto Édouard Levé fazia essa viagem solitária para fotografar, sofreu uma crise séria de depressão e que o exercício da escrita teria servido para ele como uma possibilidade de ocupar sua mente, passar a noite e chegar inteiro para mais um dia de trabalho.

Em Autoportrait, Édouard Levé diz ininterruptamente o que pensa, lembra, imagina, conjectura e sonha. Ele se comunica por frases curtas e incisivas, fragmentos de uma imagem que o leitor só poderá compor ao final de toda a leitura, já que o discurso é desconexo e as idéias não se desenvolvem. Aí, as possibilidades de compreensão não crescem ou se ampliam, mas se multiplicam e se diversificam. O que é dito pode, ou não, ter alguma relação com algo dito anteriormente ou que se dirá no futuro. O mesmo Jacques Morice (2007) explica que o texto de Édouard Levé, tal como está publicado em Autoportrait, segue a ordem em que foi escrito, havendo retoques apenas no início e no fim. Ao leitor cabe esperar por mais detalhes ou imaginar antecedentes e desdobramentos para aquilo que lhe é dito de supetão.

\footnotetext{
${ }^{9}$ Édouard Levé. Amérique. Paris: Léo Scheer, 2006.
}

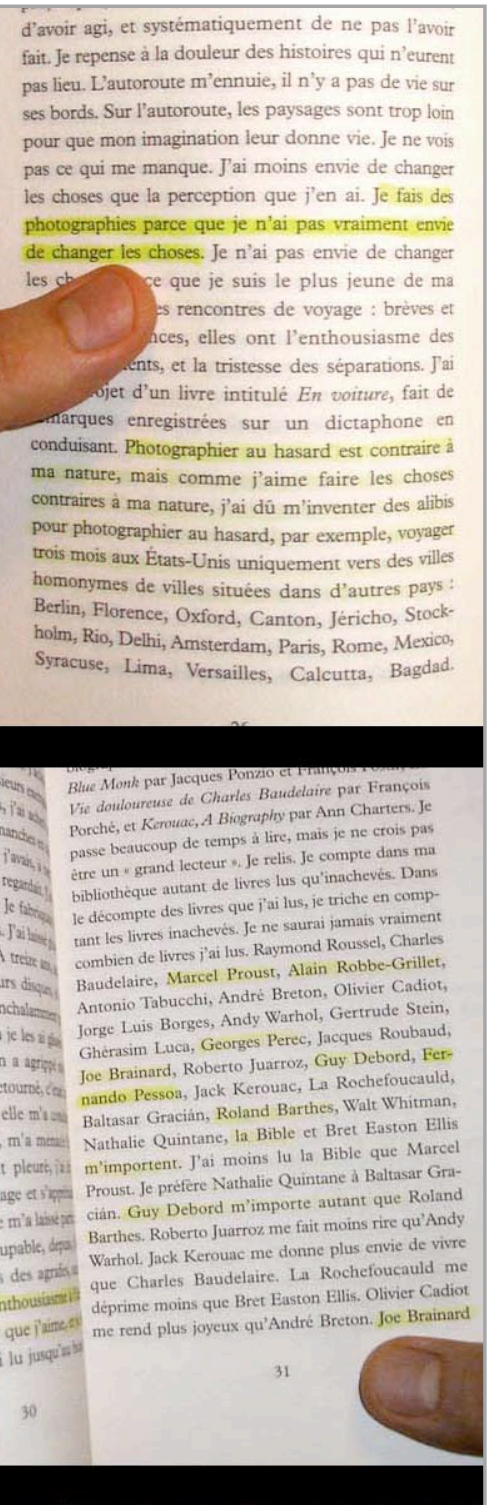

racián me rend plus intelligent. Ger des textes plus insensés que Jorge I plus facilement Bret Easton Ellis e and Roussel. Je connais moins Ja que Georges Perec. Ghérasim Luc: péré. Je 7 ois pas de rapport e-Grille tonio Tabucchi. Q istes je redoute les oublis -he éteindre. Je lis plus le midi. Je lis sans lunet res de mes yeux. Je comm cinquième minute. Je lis ni pantalon. Les soirs de ple orique sans raison. Je ne lis pas plage, je commence par m'ennu situe, et je n'arrive plus à partir. $S$ 
A descrição que Édouard Levé faz da sua atividade fotográfica ajuda a entender um pouco aquilo que atrai seu olhar e alimenta seu interesse no campo da expressão: explorar a banalidade, revelar o desimportante e retratar o que exemplifica o mediano, o igualitário o comum, aquilo e aquele onde as 'marcas da vida são discretas'. Na composição dos trabalhos fotográficos - e isso dá novo sentido às suas frases curtas - ele explica que suas imagens são estáticas e concebidas de maneira a compor um sistema de unidades autônomas, com o sentido delimitado pelas bordas.

Se no trabalho fotográfico não existem 'sequências', mas 'séries', o mesmo se passa com Autoportrait, onde vários temas são tratados tanto no interior de uma única frase, como num grupo de frases, contíguas ou não. Um exemplo disso é quando ele cita numa única frase as várias maneiras que ele fez amor: em pé, deitado, sentado, ajoelhado, etc. Num momento seguinte ele retoma o mesmo tema para falar com quem ele fez amor: a dois, a três, a muitos... Em outros momentos, perdidos entre novas preocupações, ele retoma o tema para dizer que não fez amor com a mulher de um amigo, ou ainda, que não fez amor com um homem.

O tempo verbal mais frequente em Autoportrait é aquele que designa o momento preferido

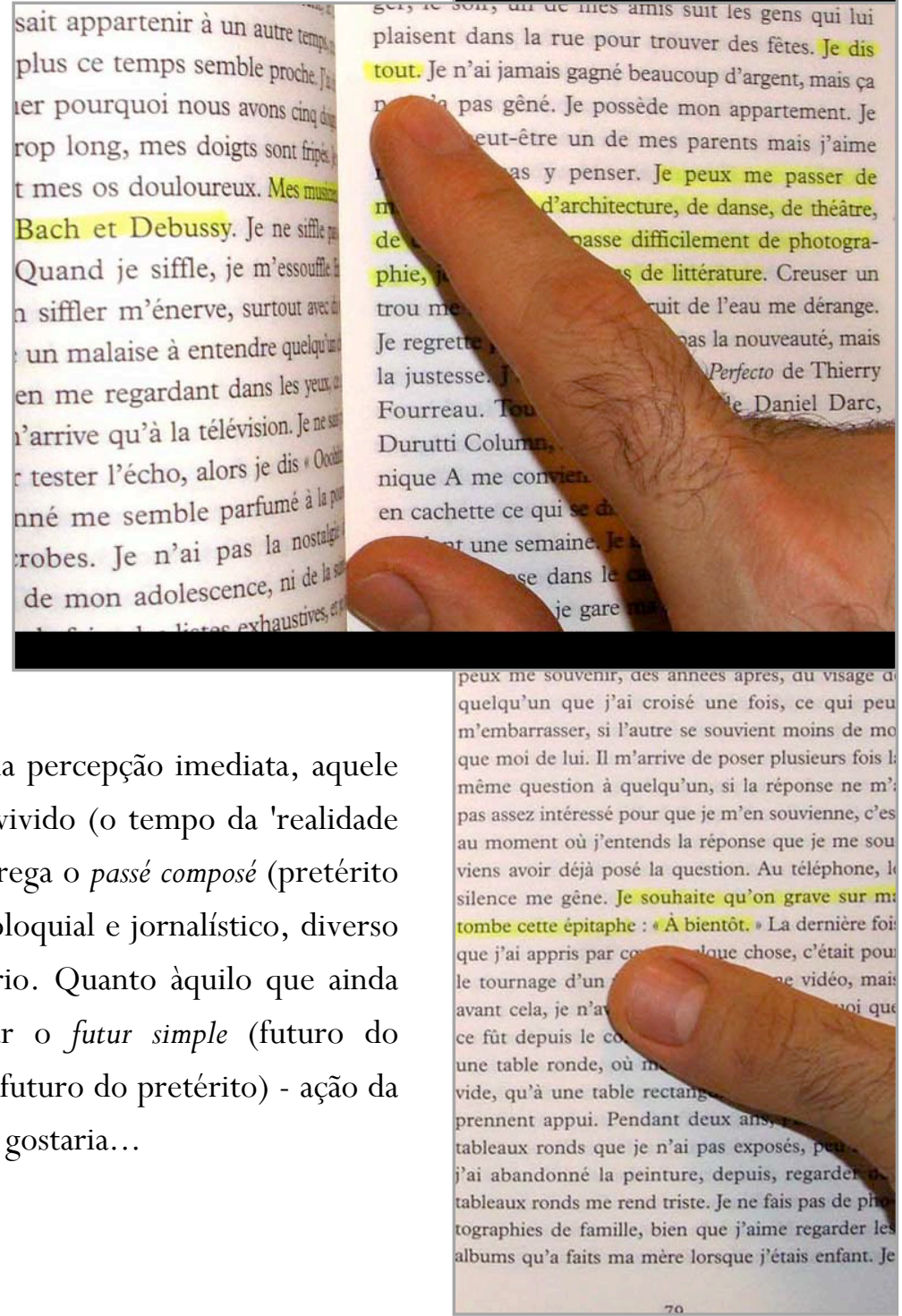

apparait dans le pare-brise cinématographique. J'écris pet plus avoir à parler. Jai acheté escroc souriant. Je n'explique Je ne classe pas. Je vais vite. gens don- 'Darle à quelqu' pas gré la difficult

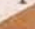
" l'ami dor atre parachute demi-heure couc veil a sonné. Je préfèr cveiller, mais je préfère vivı réponds pas aux remarques de les oublie pas. Certaines persc quelques instants car is sas do autor: o presente, tempo verbal da percepção imediata, aquele que registra o instante do momento vivido (o tempo da 'realidade fotográfica'). Para o passado, ele emprega o passé composé (pretérito perfeito), tempo verbal do registro coloquial e jornalístico, diverso do passé simple, essencialmente literário. Quanto àquilo que ainda está por vir, ao invés de empregar o futur simple (futuro do presente), ele recorre ao conditionnel (futuro do pretérito) - ação da expressão das fantasias e do desejo: eu gostaria... 
Embora o autor não explicite em Autoportrait o momento psicológico difícil pelo qual passava e que, de certa forma, foi seu estímulo, ele deixa ali várias marcas da angústia permanente que vive ao abordar compulsivamente seus temores, dúvidas e fantasmas em relação à morte. Mas isso não torna seu texto mórbido ou lamentoso, já que são frequentes as expressões ou observações de humor que injetam pontos de luz e cor na narrativa, quebrando a seriedade dos assuntos tratados e a aspereza da forma escolhida. Reconheço também aí um recurso utilizado pelo autor para conter nossa emoção e definir os limites da sua escritura como um 'campo de ações medianas', onde os extremos não são aceitos.

Em certo momento ele diz almejar uma comunicação direta e impessoal com seu leitor por meio de uma 'escritura branca', ainda que essa não exista. Nesse exercício utópico de linguagem, ele elimina superficialidades e rejeita o sentimentalismo para reafirmar a veracidade do seu relato, não se interessando por aquilo que julga ser o trabalho do poeta: criar uma língua própria. $\mathrm{O}$ interesse de

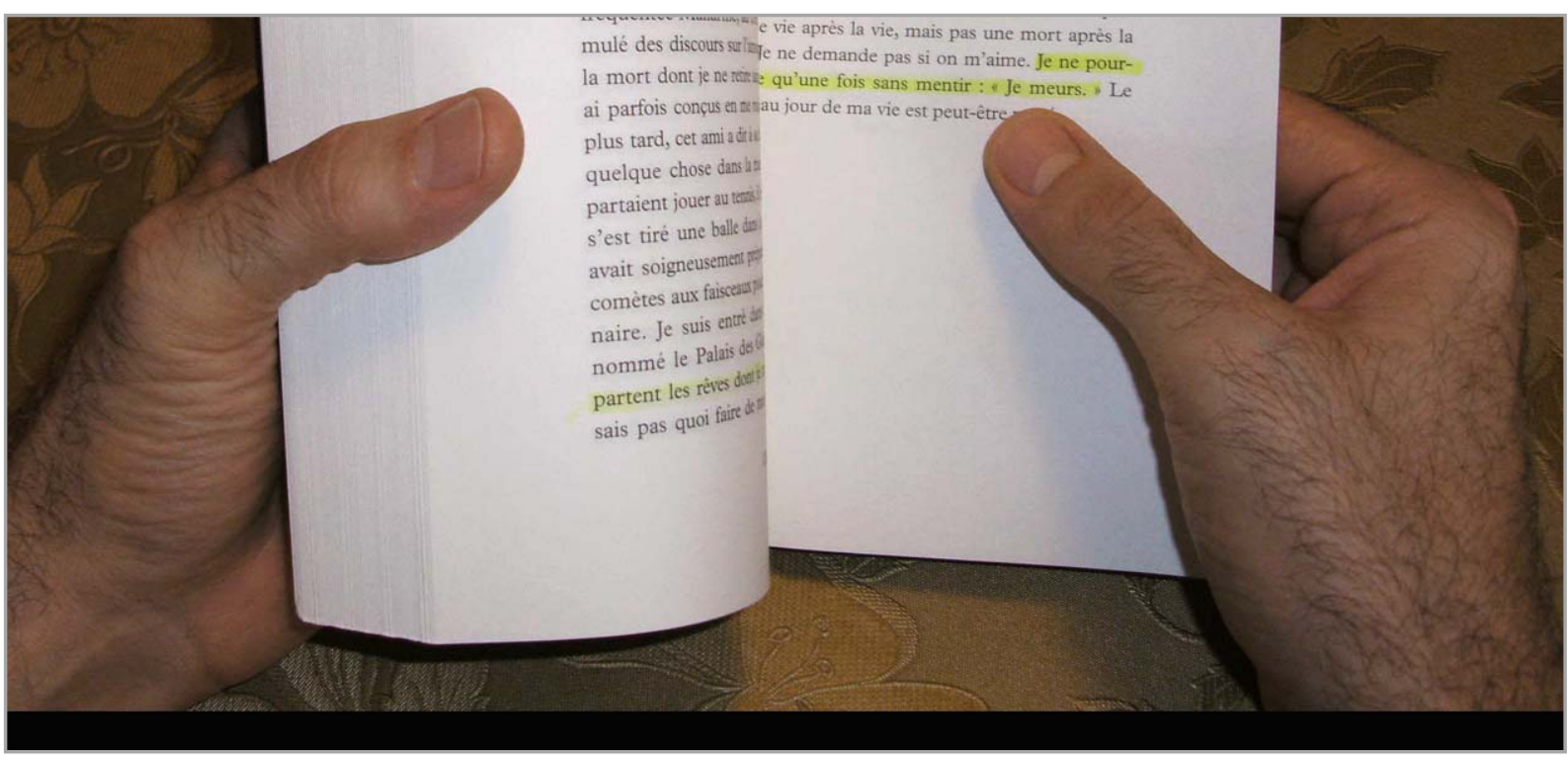

Édouard Levé está na neutralidade e no anonimato da língua comum que permite fazer do relato factual a poesia mais bela — ainda que não poética.

Na entrevista com Mathilde Villeneuve (2003), antes ainda de escrever Autoportrait, o autor estabelecia uma relação entre a sua fotografia e a sua escritura dizendo que sua escritura era branca e sua 
fotografia neutra. Ele definia seu trabalho como sendo daquele que se esforça por apagar tudo o que se apresenta 'a mais' e assim conseguir expor o essencial. O limite desse apagamento seria o gesto que, a mais, apagaria o traço mínimo da sua intenção. Ao propor ao leitor uma 'escritura mínima' ele queria instigá-lo a exercitar uma imaginação máxima.

Logo que Autoportrait é lançado, Édouard Levé é questionado (MORICE, 2007) sobre seus motivos para escrevê-lo e reconhece que, passada a turbulência vivida e a obra realizada, o objetivo inicial havia perdido seu sentido: a urgência em deixar um traço de si perante a morte eminente - o que obviamente não ocorreu. $\mathrm{O}$ autor define então sua escritura imediata e desesperada como: "[...] une empreinte de mon cerveau, obsessionnel et primesautier". (“[...] uma impressão do meu cérebro, obsessivo e impulsivo.") (negrito nosso). Assim, como cópia 'mecânica, direta e automática' do cérebro, Autoportrait inspira um gênero novo, executado no campo limítrofe do desespero humano: a 'impressão',

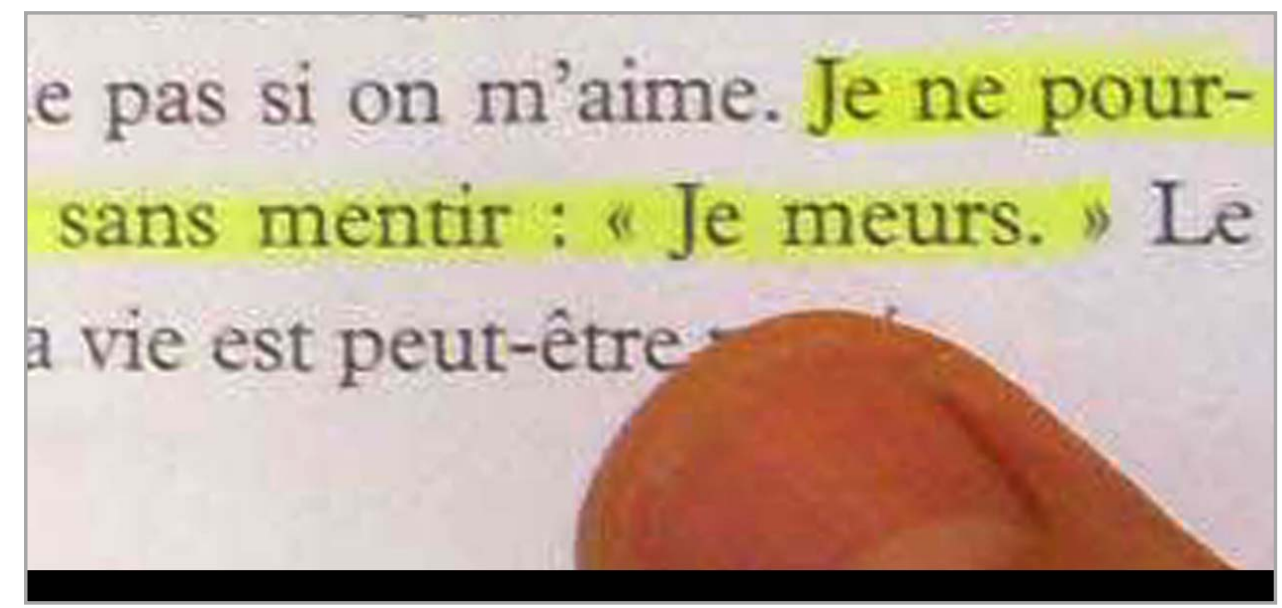

onde qualquer gesto a mais será o apagamento total, ou então, a ficção.

\section{Referências bibliográficas}

MORICE, Jacques. Edouard Levé, autoportrait pour Télérama. Télérama nº 2888, 2005. In: L'écrivain et photographe Edouard Levé est mort. Télérama. 22 oct. 2007. Disponível em: <http://www.telerama.fr/livre/20937-ecrivain_et_photographe_edouard_leve_est_mort.php>. Acesso em: 16 dez. 2009.

VILLENEUVE, Mathilde. Interview - Edouard Levé. Paris-Art. Novembre 2003. Disponível em: <http://www.paris-art.com/interview-artiste/Édouard\%20Levé/Levé-Edouard/31.html>. Acesso em: 11 dez. 2009.

Referência eletrônica: Speranzini, Manlio. Três formas mutantes do eu, Revista Criação \& Crítica (online), n. 4, p. 230-248, 2010. Disponível em:

<http://www.fflch.usp.br/dlm/criacaoecritica/dmdocuments/19CC_N4_resMSperanzini.pdf> 